\title{
Interventricular Septum
}

National Cancer Institute

\section{Source}

National Cancer Institute. Interventricular Septum. NCI Thesaurus. Code C32874.

The wall that separates the left and right ventricles of the heart. 